\title{
Critical Analysis of the Public Regional Programs on Energy Efficiency in the Context of Housing and Utilities Sector
}

\author{
Olga I. Dobrynina \\ Nikolay N. Minaev \\ Kristina E. Filushina \\ Yulia A. Kolykhayeva \\ Ekaterina A. Zharova \\ Tomsk State University of Architecture and Building, Russian Federation \\ Email: Dobrynina_Oly@mail.ru
}

\section{Doi:10.5901/mjss.2015.v6n3s5p127}

\begin{abstract}
Relevance of the study is defined by the large-scale aspirations of the state to enhance the processes of energy saving and energy efficiency in the sectors of the national economy. First of all, this concerns the energy-intensive industries, such as housing and utilities sector. Nodal stage and formalization of these processes are the public regional energy savings that have been developed, adopted and implemented since 2010. The aim of the study is to conduct a critical analysis of management models of the public regional programs of energy saving and energy efficiency in the context of housing complex. In particular, form the perspective of the changing Russian legislation in the sphere of the utilities sector and the new conditions and requirements for the subjects of housing and communal relations and management of public utilities complex. At the federal level, this has resulted in the development and adoption of a number of basic legal acts in the field of public utilities regulations of the Government of the Russian Federation. The study revealed a number of obstacles to the successful implementation of energy saving policy in the utility sector, highlighted key weaknesses of regional energy efficiency programs, and identified the ways of their improvement in relation to the relevant processes in the housing sector, as the main energy consumer and producer.
\end{abstract}

Keywords: energy conservation, housing and utilities sector, region, regional programs

\section{Introduction}

Since 2008 , there has been serious attempts to obtain a certain impetus to the development of the Russian economy by increasing the effectiveness of innovation processes. This was reflected in certain key development vector - promotion of energy conservation and energy efficiency in the real economy. It was felt vindicated by comparing similar phenomena with Western experience that the main reason for lack of competitiveness of Russian goods and services in the global market is excessively high proportion of energy waste in their production. Therefore, there was a task at the state level to activate the process of energy saving and energy efficiency in energy-intensive industries, while the development of public regional energy saving program was supposed to provide the necessary mechanism. Over the past few years, an extensive experience is accumulated in the implementation of such programs, which certainly should get a critical evaluation. Given that the housing complexes remain the main consumer of energy in the national economy, the main objective of the study is to answer the question on the reasons for the lack of the expected results in the housing and utilities sector.

At the same time, it is important and necessary to define what is a modern housing and utilities sector, its role and importance. Housing and utilities sector (HUS) is a key territorial business unit, providing sustainable infrastructure development of Russian regions in addressing critical social and economic problems. However, for a long time HUS is in a state of systemic crisis caused by the lack of a balanced management policy (as well as tariff and technical policy), the state of emergency housing and communal infrastructure, lack of investment (linked to high risk) in the development of the material-technical base and the lack of effective public-private partnership, high energy losses during production and 
transportation of utilities, and finally, the lack of clear innovation policies aimed at improving the functioning of the subjects of housing and communal relations.

Governance of the processes of implementation of the energy saving technologies and measures to improve energy efficiency in the HUS should be a priority in the documents of regional development of energy saving. Thus, the following objectives are defined for this study: evaluation of the developed public regional energy efficiency programs and their comparison with the patterns of HUS development; allocation of disadvantages of the regional programs; identify areas of improvement.

\section{Technologies and Measures Over Energy Efficiency}

The problems of resource and energy efficiency in the framework of national economy are extensively studied by Aslanyan and Solovyanov (1998), Boxes (1974), Breeden (2007), Volfberg (1999), Lewis (1986), Nurmahmatov (2006) and a number of other scholars. The economic content of the process of energy saving in the HUS is reflected in the works of Chernyshev (2010), Titov (2008), Uvarov and Stavtsev (2009). Research of Asaul, et al. (2005) and Bessonova (2012) is focused on the problems of economic and technological nature. Despite the fact that energy conservation and energy efficiency has attracted the attention of a large number of scientists over the recent years, it is impossible to allocate significant research dedicated to the issues of assessing the effectiveness of public regional energy efficiency programs and energy efficiency in the context HUS, thus, leaving this particular aspect unexplored.

The methodological basis of the study forms the institutional concept, the choice of which is due to the necessity of formulating and solving problems of ordering the energy saving management processes in the HUS complex. The study uses the principles and methods of subject-logical and structural-functional analysis, statistical processing of raw data and results. Evidence base are the official statistics and other domestic and foreign documents, conference materials, domestic and foreign publications, as well as the results of the scientific research project, conducted under the financial support of the grant RHF "Management models of energy saving in housing and communal complexes and the development of scenarios of innovative development of housing and utilities sector of the Siberian city", № 10-02$64201 \mathrm{a} / \mathrm{T}$, as well as the actualization of a series of previously obtained scientific results.

Critical analysis of the public regional programs of energy conservation and energy efficiency in the context of HUS complex revealed the following: firstly, there are major discrepancies in the typology of regional programs being developed (see Table 1). That is, there is no uniformity in the status of such documents.

Table 1. Distribution of subjects of the Russian Federation by the types of energy saving and energy efficiency programs

\begin{tabular}{cc}
\hline Program type & Number of subject of the Russian Federation \\
\hline Long-term & 27 \\
\hline Complex & 5 \\
\hline Target & 2 \\
\hline Regional & 8 \\
\hline Republican & 15 \\
\hline Krai & 3 \\
\hline Oblast & 17 \\
\hline State & 1 \\
\hline District & 2 \\
\hline Other & 2 \\
\hline
\end{tabular}

Moreover, as developers perform a variety of subjects (e.g. ministries, departments, offices and special committees, as well as various kinds of partnerships and societies, educational institutions). There are a number of programs with the developers not being listed at all, as well as programs in the development of which there is a complex interaction of actors.

Secondly, as certain regularity, we shall note that the implementation of all processes and activities related to energy conservation are focused in two main areas: firstly, energy efficiency in system of the national economy, which will enable to increase the competitiveness of domestic products. Since the share of material costs in the cost structure is generally being at the level of $60-70 \%$ and above, and the cost of fuel and energy takes about the same parameters in the cost structure, it is obviously necessary to minimize the costs associated with energy consumption in order to increase the competitiveness of national industrial products. Secondly, increase in the level and quality of life. Today, the 
main consumer of energy among all sectors of the national economy is the HUS. It accounts for about a quarter of all energy consumed. And, accordingly, reducing energy consumption, thereby reduces the cost of housing and communal services, which ultimately improves the level and quality of life, exempt certain funds that people can spend on more useful things (Filyushina et al., 2014). This direction is one of the main priorities for the development of the national economy of the Russian Federation and without the implementation of these activities it is impossible to achieve the effects that are found in programs of social and economic development.

Thirdly, the amount of funding of the energy efficiency programs vary significantly by region. Research results suggest that the volumes of funds, which are designated in these programs, are insufficiently justified because the real need for the introduction of resource-saving technologies is much higher. There is a tendency to the fact that funding for these programs is carried out on the "leftovers" manner, therefore, in most regions the energy saving program are not funded in full. In addition, there is no comparable financing programs across the regions (see Table 2).

Table 2. The volume of funding the regional energy saving and energy efficiency programs

\begin{tabular}{|c|c|c|c|}
\hline Regions of Russia & $\begin{array}{l}\text { Financial support of the } \\
\text { program, bln. rubles }\end{array}$ & $\begin{array}{c}\text { Population, thous. } \\
\text { pers. }\end{array}$ & $\begin{array}{l}\text { Program financing, mln. } \\
\text { rubles per person }\end{array}$ \\
\hline \multicolumn{4}{|l|}{ Central Federal District } \\
\hline Belgorod region & 6.62 & 1547.9 & 4.28 \\
\hline Bryansk region & 4.46 & 1232.94 & 3.62 \\
\hline Vladimir region & 3.33 & 1405.61 & 2.37 \\
\hline Voronezh region & 23.58 & 2331.14 & 10.12 \\
\hline Ivanovo region & 0.36 & 1036.90 & 0.35 \\
\hline Kaluga region & 14.21 & 1010.48 & 14.06 \\
\hline Kostroma region & 12.72 & 654.39 & 19.44 \\
\hline Kursk region & 32.48 & 1117.37 & 29.07 \\
\hline Lipetsk region & 0.97 & 1157.86 & 0.84 \\
\hline Moscow & 219.74 & 12197.59 & 18.02 \\
\hline Moscow region & 330.52 & 7231.07 & 45.71 \\
\hline Oryol Region & 18.15 & 765.23 & 23.72 \\
\hline Ryazan region & 2.21 & 1135.44 & 1.95 \\
\hline Smolensk region & 14.02 & 964.79 & 14.53 \\
\hline Tambov Region & 15.58 & 1062.42 & 14.66 \\
\hline Tver region & 3.68 & 1315.07 & 2.80 \\
\hline Tula region & 42.99 & 1513.57 & 28.40 \\
\hline Yaroslavl region & 11.28 & 1271.63 & 8.87 \\
\hline \multicolumn{4}{|l|}{ Southern Federal District } \\
\hline Republic of Adygea & 2.34 & 449.17 & 5.21 \\
\hline Astrakhan region & 13.52 & 1021.29 & 13.24 \\
\hline Volgograd region & 160.98 & 2557.39 & 62.95 \\
\hline Republic of Kalmykia & 0.45 & 280.56 & 1.60 \\
\hline Krasnodar Krai & 168.71 & 5453.33 & 30.94 \\
\hline Rostov region & 24.4 & 4242.08 & 5.75 \\
\hline \multicolumn{4}{|l|}{ Northwestern Federal District } \\
\hline Arkhangelsk region & 13.8 & 1183.32 & 11.66 \\
\hline Vologda region & 57.72 & 1191.01 & 48.46 \\
\hline Kaliningrad region & 11.08 & 968.94 & 11.44 \\
\hline The Republic of Karelia & 13.02 & 632.53 & 20.58 \\
\hline Komi Republic & 7.50 & 864.42 & 8.68 \\
\hline Leningrad region & 14.32 & 1775.54 & 8.07 \\
\hline Murmansk region & 4.7 & 766.28 & 6.13 \\
\hline Nenets Autonomous Okrug & 146.47 & 43.37 & 3377.22 \\
\hline Novgorod region & 2.73 & 618.70 & 4.41 \\
\hline Pskov region & 2.66 & 651.10 & 4.09 \\
\hline St. Petersburg & - & 5191.69 & - \\
\hline \multicolumn{4}{|l|}{ Far Eastern Federal District } \\
\hline Amur region & 9.37 & 809.87 & 11.57 \\
\hline Jewish Autonomous Region & 0.26 & 168.37 & 1.54 \\
\hline Kamchatka Krai & 0.13 & 317.27 & 0.41 \\
\hline Magadan region & 0.43 & 148.07 & 2.90 \\
\hline
\end{tabular}




\begin{tabular}{|c|c|c|c|}
\hline Primorsky Krai & 11.27 & 1933.31 & 5.83 \\
\hline Republic of Sakha (Yakutia) & 29.655 & 956.89 & 30.99 \\
\hline Sakhalin Region & 3.47 & 488.39 & 7.10 \\
\hline Khabarovsk Krai & 1.92 & 1338.31 & 1.43 \\
\hline Chukotka Autonomous District & 0.52 & 50.54 & 10.29 \\
\hline \multicolumn{4}{|l|}{ Siberian Federal District } \\
\hline Republic of Altai & 4.18 & 213.70 & 19.56 \\
\hline Altaiskii krai & 5.78 & 2384.81 & 2.42 \\
\hline Republic of Buryatia & 9.7 & 978.49 & 9.91 \\
\hline Trans-Baikal Krai & 1.31 & 1087.45 & 1.20 \\
\hline Irkutsk region & 1.94 & 2414.91 & 0.80 \\
\hline Kemerovo region & 57.99 & 2724.99 & 21.28 \\
\hline Krasnoyarsk Krai & 2.06 & 2858.77 & 0.72 \\
\hline Novosibirsk region & 1.84 & 2746.82 & 0.67 \\
\hline Omsk region & 0.43 & 1978.18 & 0.22 \\
\hline Tomsk region & 214.38 & 1074.45 & 199.53 \\
\hline Republic of Tyva & 1.34 & 313.77 & 4.27 \\
\hline Republic of Khakassia & 1.06 & 535.79 & 1.98 \\
\hline \multicolumn{4}{|l|}{ Ural Federal District } \\
\hline Kurgan region & 5.75 & 869.81 & 6.61 \\
\hline Sverdlovsk region & 110.26 & 4327.47 & 25.48 \\
\hline Tyumen region & 105.68 & 3581.29 & 29.51 \\
\hline $\begin{array}{l}\text { Khanty-Mansi Autonomous District - } \\
\text { Yugra }\end{array}$ & 114.52 & 1612.08 & 71.04 \\
\hline Chelyabinsk region & 19.5 & 3497.27 & 5.58 \\
\hline Yamal-Nenets Autonomous District & 146.47 & 539.97 & 271.26 \\
\hline \multicolumn{4}{|l|}{ Volga Federal District } \\
\hline Republic of Bashkortostan & 82.9 & 4071.99 & 20.36 \\
\hline Kirov region & 63.53 & 1304.35 & 48.71 \\
\hline Republic of Mari El & 4.6 & 687.44 & 6.69 \\
\hline Republic of Mordovia & 11 & 808.89 & 13.60 \\
\hline Nizhny Novgorod region & 35.81 & 3270.20 & 10.95 \\
\hline Orenburg region & 50.99 & 2001.11 & 25.48 \\
\hline Penza region & 35.56 & 1355.62 & 26.23 \\
\hline Perm Krai & 3.35 & 2637.03 & 1.27 \\
\hline Samara Region & 2.09 & 3212.68 & 0.65 \\
\hline Saratov region & 17.83 & 2493.02 & 7.15 \\
\hline Republic of Tatarstan & 0.23 & 3855.04 & 0.06 \\
\hline Udmurt Republic & 6.96 & 1517.47 & 4.59 \\
\hline Ulyanovsk region & 5.99 & 1262.55 & 4.74 \\
\hline Republic of Chuvashia & 25.18 & 1238.07 & 20.34 \\
\hline \multicolumn{4}{|l|}{ North Caucasian Federal District } \\
\hline Republic of Dagestan & 17.56 & 2990.37 & 5.87 \\
\hline Republic of Ingushetia & 17.81 & 463.89 & 38.39 \\
\hline Kabardino-Balkar Republic & 2.37 & 860.71 & 2.75 \\
\hline Republic of Karachay-Cherkessia & 55.86 & 469.06 & 119.09 \\
\hline Republic of North Ossetia-Alania & 3.56 & 705.27 & 5.05 \\
\hline Chechen Republic & 11.02 & 1370.27 & 8.04 \\
\hline Stavropol Krai & 4.29 & 2799.47 & 1.53 \\
\hline
\end{tabular}

Source: Author elaboration based on population census and program documents.

As shown in the table 2, the differences in the program financing per capita are significant and the gaps reach up to tens of times. This testifies to the unbalanced policy at the federal level, and a different attitude to the process of energy conservation at the regional level.

Fourthly, given that the main energy consumer in the national economy is the housing complex, all the energy saving programs should be coordinated with the development programs of the HUS, but this is not the case. To date, the presence of energy-saving measures in the HUS are being implemented only in 58 regions, of which 18 subjects of the Russian Federation presented the energy saving measures in the form of the development of individual subprograms, all 
the rest are presented as separate events. However, there are opposite examples. As a positive example we shall note that in the Trans-Baikal Krai is developed a separate program on energy saving in HUS. However, since there is no general agreement with the sectoral strategies, inevitably arises question about the quality of regional energy efficiency programs. They are characterized by the fact that at the moment there are no real, tangible effects on the reduction of energy consumption in the production structure of utility services. At the same time, there is an absolute increase in tariffs, and this growth is artificially constrained by the federal government at no more than $15 \%$ per year.

Fifthly, implementation of programs and their respective activities are associated with certain risks. Risk assessment in the implementation of energy saving projects is an integral part of the feasibility study of the underlying activities of investment projects. It is also generally overlooked by the regions, in fact, only six regions (Moscow, Tver region, Kostroma region, Volgograd region, Tomsk region, Udmurtia region) made this assessment. However, the question remains on the methodology and methodological support of the programming process. In fact, there is a situation when the program does not assess the risk of its performance or non-performance, and this in turn affects the final efficiency, including as expressed in certain financial indicators (Minaev et al., 2014a, 2014b).

Finally, nearly all regions have established regional operators associated with the formation of the capital renovation fund. This is perhaps the largest regional financial funds that will exist over the next decade. Their tasks are clearly marked - the capital renovation of the housing stock throughout Russia and bringing it up to standard. The calculations were made, budgets are predefined, which should be formed on the basis of the calculated rates. It is evident that carrying out work related to major repairs is the opportunity to improve the energy efficiency of our housing stock and to reduce power consumption and thereby reduce the burden of HUS on the population. For the reference purpose, the Table 3 shows the grouping of regions by the rate for major repairs (per 1 sq.m.) and the estimation of needs of the regions in financing the capital renovation programs.

Table 3. Grouping of regions by the rate for major repairs and financial requirements

\begin{tabular}{lccccccccc}
\hline \multicolumn{1}{c}{ Rate per 1 sq.m., rub. } & under $\mathbf{2 . 5}$ & $\mathbf{2 . 5 - 3 . 5}$ & $\mathbf{3 . 5 - 4 . 5}$ & $\mathbf{4 . 5 - 5 . 5}$ & $\mathbf{5 . 5 - 6 . 5}$ & $\mathbf{6 . 5 - 7 . 5}$ & $\mathbf{7 . 5 - 8 . 5}$ & $\mathbf{8 . 5 - 1 0}$ & $\mathbf{1 0 - 1 5}$ \\
\hline Total number of subjects in the group & 1 & 2 & 4 & 13 & 31 & 22 & 5 & 2 & 3 \\
\hline Total population, mln pers. & 5.13 & 1.64 & 3.13 & 21.86 & 51.71 & 33.17 & 5.29 & 2.42 & 5.68 \\
\hline mIn.sq.m. & 111.04 & 18.86 & 26.32 & 140.62 & 582.46 & 6479.37 & 28.61 & 31.7 & 32.83 \\
\hline Annual funding, bln. rub. & 2.7 & 0.66 & 1.3 & 0.95 & 43.7 & 504.5 & 2.7 & 4.07 & 3.6 \\
\hline
\end{tabular}

Source: based on regional programs for capital renovation and census data.

\section{Concluding Remarks}

Based on the given analysis, we can conclude that the considered regional energy saving programs require a more thorough revision in part: of the development of a unified methodology of regional energy efficiency saving and energy efficiency programs, including the formation of a unified register of developers who have the necessary skills and knowledge of such works; adequacy of the level of funding for the regional energy saving programs. In terms of regions, this amount should not vary significantly in per capita terms; harmonization of regional energy saving programs with programs of the HUS (and, in general, the other sectoral regional programs), as a key energy consumer; as well as of the regional energy saving programs with substantial and relevant process - implementation of regional programs on capital renovation of the housing stock. Planned work in the overhaul should take into account the requirements of energy efficiency. As the result, it is expected to increase the energy efficiency class of the residential buildings, expressed in the reduction of energy consumption.

The following factors have to be taken into account:

- the parameters and indicators of the quality of life generally reflected in the regional programs of socioeconomic development. However, it requires additional study in the context of regional particularities and specificities;

- the factors of the emergence of technological risks in the process of production, transportation and energy consumption, as the HUS applies to most hazardous industry, due to the high depreciation of fixed assets;

- the factors of risks in the implementation of regional programs. It is necessary to develop a system of risk assessment, which includes an external and intra-industry risks (changes in the socio-economic situation, the external market prices on energy resources, changes in the technological level, etc.).

Successful implementation of the modernized regional energy efficiency programs in HUS will reduce the cost of 
housing and communal services, which remain at the level of 10-20\%, often exceeding the level of $25 \%$ of the total costs. In addition, during the recession of the Russian economy, reduction in the energy consumption for the production of domestic products will enhance the process of import substitution and increase its competitiveness, which in turn significantly mitigate the impact of adverse external conditions.

\section{Acknowledgment}

Article is written within the public task of the Russian Ministry № 577 "Investigation of regularities on the management processes to increase energy efficiency and economic feasibility of introduction of energy saving technologies in housing and communal services"

\section{References}

Asaul, A.N., Kazakov, Yu., Pasiada, N.I., \& Denisova, I.V. (2005). Low-rise housing. St. Petersburg: Gumanistika.

Aslanyan, G.S., \& Solovyanov, A.A. (1998). Energy conservation as an essential component of environ-policy. Thermal Engineering, 1, 76-82.

Bessonova, O.E. (2012). Housing model in the structure of institutional matrix: the logic of transformation. Society and economy, 2, 5978.

Boxes, D. (1974). Time series analysi. Prognosis and management. Moscow: Mir.

Breeden, A. (2007). Involvement of international standards for activities. Therefore suit rational approach to energy. World standards, 1 , 23-27.

Chernyshev, L.N. (2010). Rationale for the economic efficiency of the municipal program to eliminate uncomfortable accommodation. Utilities. Economics and business management utilities, 1(1),11-15.

Lewis, K.D. (1986). Methods of forecasting economic indicators. Moscow: Finance and Statistics.

Minaev, N.N., Filyushina, K.E., \& Dobrynina, O.I. (2014a). Risks arising from the implementation of energy efficiency programs in the residential complex. Scientific Review, 8(1), 397-400.

Minaev, N.N., Filyushina, K.E., \& Dobrynina, O.I. (2014b). Analysis of the development of processes to improve energy efficiency and energy saving in housing complexes. Economics and Entrepreneurship, 6, 104-110.

Nurmahmatov, D.N. (2006). The strategy of development of electric power in Tajikistan. Energy Drink, 4, 10-12.

Titov, G.R. (2008). The use of nanotechnology for energy savings in outdoor lighting and public utilities Moscow. Energy saving, 5, 6869.

Uvarov, A.B., \& Stavtsev D.A. (2009). Study of the potential of solar energy for energy saving in the construction industry and housing. Herald of Orel State Agrarian University, 20(5), 32-35.

Volfberg, D.B. (1999). Current status and prospects of development of the energy industry worldwide. Thermal Engineering, 8, 5-12. 